\title{
First Limnological Characterization of the Tropical Crater Lake Amparihibe in the Makira Protected Area, Madagascar
}

\author{
Robert Schabetsberger ${ }^{1}$, Eugen Rott ${ }^{2}$, Gertrude Friedll ${ }^{3}$, Gabriele Drozdowski ${ }^{1}$ Estelle Razafindranaivo ${ }^{4}$ \\ \& Christopher Holmes ${ }^{5}$
}

Keywords: endemism, limnology, Madagascar, plankłon

\section{Abstract}

The newly established Makira Protected Area and its environs in Northeast Madagascar host roughly $50 \%$ of the entire Malagasy floral biodiversity, but very little was known about the two freshwater lakes found within the park. Lake Amparihibe was explored for the first time in November 2007. According to preliminary $40 \mathrm{Ar} / 39 \mathrm{Ar}$ dating, the volcanic crater formed as far back as 25.3 million years ago, but no information is available about when the crater started to fill with water. The protected crater lake has a maximum depth of $28 \mathrm{~m}$ and was anoxic beyond a depth of $15 \mathrm{~m}$. During the single sampling occasion, steep gradients in temperature, oxygen, conductivity and $\mathrm{pH}$ revealed a stable stratification. Several phyto- and zooplankton taxa showed distinct depth-specific abundance maxima along the steep physico-chemical gradients. The majority of plankton organisms have a cosmopolitan (tropical and temperate) distribution, however more taxonomic research is necessary before definitive conclusions can be drawn. Exposure of a multi-mesh gill net together with visual inspection by snorkeling yielded no presence of fish. Despite the full protection status of the park, illegal introduction of alien fish species seems a realistic threat to this pristine Malagasy lake.
Profile

Protected area

Makira Protected Area

Mountain range

Ampokafobe Plateau

Country

Madagascar

\section{Introduction}

The island of Madagascar has been separated from the African mainland for about 165 million years (Rabinowitz et al. 1983), and it has been isolated from all other land masses, most recently from India, for approximately 90 million years (Raval \& Veeraswamy 2003). Due to this long isolation a unique fauna and flora has evolved, characterized by high levels of endemism. Hence biologists often refer to the fourth largest island of the world as an island continent (Tyson 2000). Surveys of aquatic organisms depicted Madagascar as a global hotspot of freshwater biodiversity (Groombridge \& Jenkins 1998). Since the 1990s the number of newly described species of aquatic insects and fish has increased exponentially (Benstead et al. 2003). It is still a matter of debate, however, whether endemic species also developed in planktonic organisms. Whereas some authors state that there is indisputable evidence of endemisms and restricted geographical distributions (e.g. Dumont 1983), Fenchel and Finlay (2004) argue that all organisms with cysts $<1 \mathrm{~mm}$ should easily be dispersed across barriers such as the Mozambique channel and potentially be cosmopolitan. This contrasts with the views of other authors on phytoplankton taxa, for which group-specific endemism is assumed. In Madagascar this has been documented especially for chrysophytes (Hansen 1996; Kristiansen \& Lind 2005), diatoms (Metzeltin \& Lange-Bertalot
2002) and desmids (West \& West 1895; Bourelly \& Couté 1991). Biogeographic regions of phytoplankton taxa are becoming more and more evident (e.g. Coesel 2002). However, in contrast to benthic habitats, the number of biogeographically restricted tropical and tropicalwarm temperate phytoplankton taxa usually make up only a small proportion (not more than $10-20 \%$ ) of the overall richness of tropical lakes (see Rott et al. 2008; Schabetsberger et al. 2004).

Surveys of the Malagasy freshwater algal flora from various habitats are quite patchy (West \& West 1895; Fritsch 1914; Manguin 1941; Bourrely \& Leboime 1946; Bourrelly \& Manguin 1949). More recent

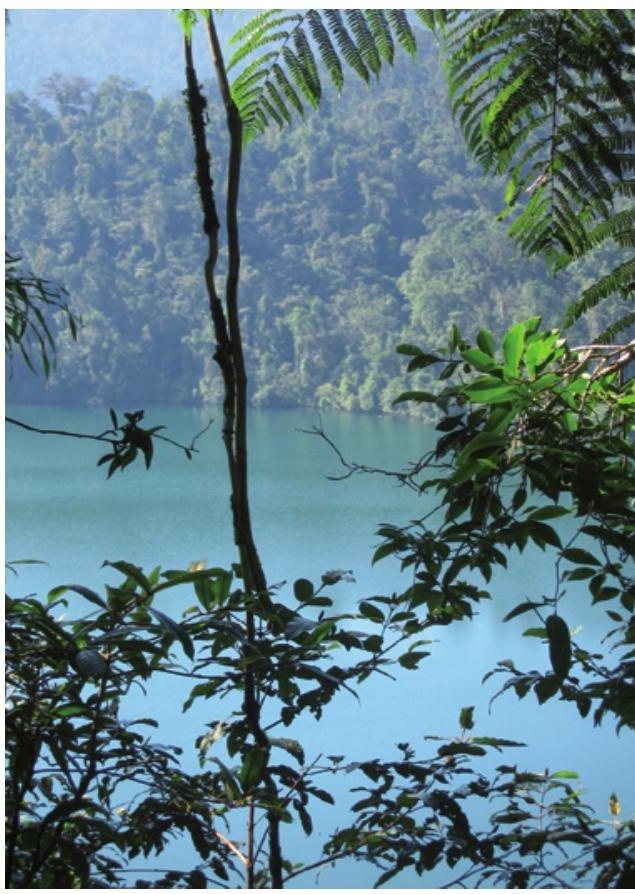

Lake Amparibibe (C) Gabriele Drozdowski algological investigations are available for mostly nonplanktonic desmids (Bourrelly \& Couté 1991; Coesel 2002), chrysophytes (Hansen 1996) and benthic diatoms from subaerial (Spaulding \& Kociolek 1998a, b) and benthic freshwater habitats (Metzeltin \& LangeBertalot 2002). Taxonomic research on micrometazoa 


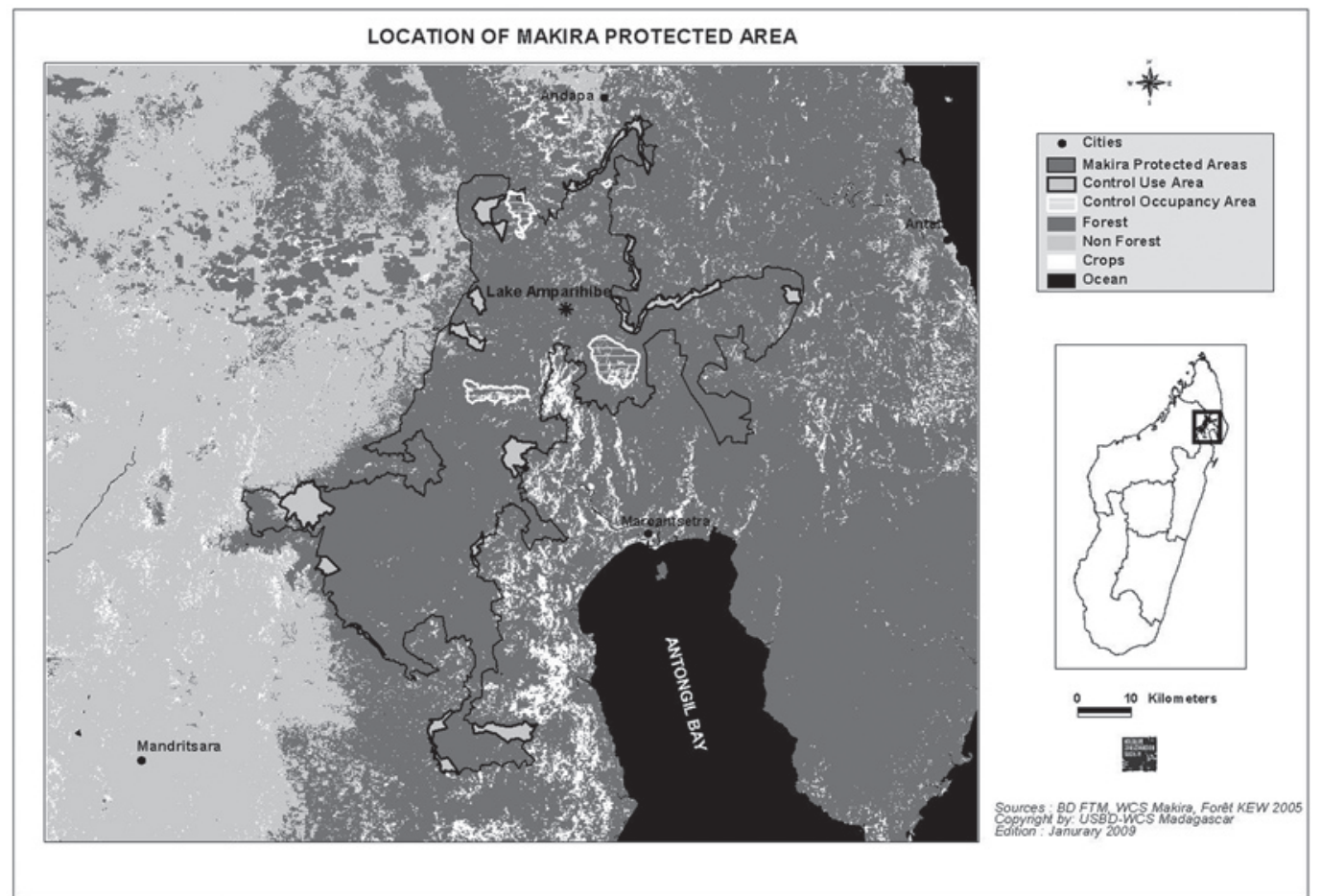

Figure 1 - Map of the Antongil Bay area in NE Madagascar showing the Masoala National Park and the Makira Protected Area. Control use area: natural resources can be harvested by local people for their living; Control occupancy area: controlled settlement of local people possible.

was conducted predominantly until the 1960 s and is also fragmentary (De Guerne \& Richard 1893; Brehm 1930; 1948; Kiefer 1930). Most studies were based on samples taken by the director of the "Institut des recherches scientifiques de Madagascar", Renauld Paulian, who sent the material to various taxonomists (Rotifera: Berzins 1960; 1973; 1982; Harpacticoida: Chappuis 1952; 1954; 1956; Calanoida: Brehm 1951; 1952 a, b, c; 1953; 1954; Cyclopoida: Lindberg 1951 a, b; 1952; 1953; Kiefer 1952; 1954; 1955; Cladocera: Brehm 1953). Brehm (1960) gave an account on freshwater crustacea collected during the Austrian Madagascar expedition in 1958. Few publications appeared after this peak period of taxonomic work on freshwater micrometazoa (Dussart 1982; Segers 1992; Fiers 2002). Although much more remains to be done, endemic algae (e.g. Metzeltin \& Lange-Bertalot 2003; Coesel 2002), rotifers (Berzins 1982), and copepods (Dussart 1982) have been discovered in Malagasy freshwater ecosystems. Dumont (1983) even called the comparatively large number of 18 endemic rotifers the "Madegassian anomaly"; however Berzin's (1960) description of the endemic genus Repauliana probably was a misidentified preservation artefact of Tetrasiphon hydrochora (W. Koste personal communication). Nevertheless a systematic survey of Malagasy lakes would contribute substantially to the question of endemic versus cosmopolitan distribution in freshwater planktonic organisms.

Systematic species inventories of pristine lakes must be started before the last natural communities may be destroyed. With a loss of $40 \%$ of rainforest cover between
1950 and 2000 (Harper et al. 2007), Madagascar anticipates the fate of tropical rainforest habitats worldwide. If deforestation of the eastern rainforest continues at the rate of $1.6 \%$ per year (102 $000 \mathrm{ha}$ ), only the steepest slopes will remain forested by 2025 (Green \& Sussman 1990). Deforestation causes increased sediment delivery and nutrient input into the lakes and hence alters physico-chemical conditions, species composition and trophic interactions (Benstead et al. 2003). In addition, alien fish species such as tilapias may be stocked once logging and slash-and-burn agriculture closes in on the lakes. These introduced fish usually cause severe changes to the entire ecosystem (Schabetsberger et al. 2009). Very likely the species communities within lakes near human settlements have long been altered. Hence Benstead et al. (2003) define three major objectives to conserve the remaining freshwater biodiversity: (1) Survey efforts have to be directed at remote regions that have not been inventoried for freshwater biota. (2) Systematic and ecological studies of poorly known taxonomic groups must be undertaken. (3) Top conservation priority should be given to intact freshwater ecosystems that are situated within protected areas. So far only few lake ecosystems in Madagascar have been investigated (see Moreau 1988 and references therein) and even fewer pristine lakes remain within the rainforests of Madagascar. Some isolated crater lakes are found in the mountainous regions of Northern Madagascar. Lake Amparihibe ("The big lake") and the considerably smaller Lake Lohanimanandriana are the only lentic water bodies within the Makira Protected Area. This newly established protected area is 
among the largest remaining contiguous areas of tropical rain forest in Madagascar and as part of the larger Antongil Bay landscape harbours roughly 50\% of the floral biodiversity found in Madagascar (Wildlife Conservation Society 2008a). Hence, the aim of this study was a first limnological characterization of Lake Amparihibe, with the focus on a survey of phyto- and zooplankton species and estimates of their densities.

\section{Materials and methods}

\section{Study site}

The Makira Protected Area covers 371456 hectares of rainforest between $50 \mathrm{~m}$ and $1200 \mathrm{~m}$ elevation. Mean annual temperatures range from 22.5 to $25.8^{\circ} \mathrm{C}$, but may drop below $15^{\circ} \mathrm{C}$ at Lake Amparihibe. Annual rainfall in the area varies between 1100 and $3500 \mathrm{~mm}$ and exceeds 180 days. It decreases during the southern winter (April to November), from East to West, and towards higher altitudes. During the summer the trade winds from the East decrease and are counterbalanced by monsoon winds from the North. The frequency of cyclones hitting the area during this rainy season increased during the last decade (one in 2000 and 2004 and two in 2007; Wildlife Conservation Society 2008b). The park contains seventeen rivers and two lakes. Lake Amparihibe, situated at an altitude of $798 \mathrm{~m}\left(15^{\circ} 2.275^{\prime} \mathrm{S}, 49^{\circ} 35.057^{\prime} \mathrm{E}\right.$; Figure 1), was reached after a one days journey by boat $(52 \mathrm{~km})$ on the river Antainambalana and a three days march (43 $\mathrm{km})$ through the rainforest. The volcanic crater lake is surrounded by intact eastern rainforest, has a diameter of $430 \mathrm{~m}$ and a maximum depth of $28 \mathrm{~m}$. The approximately $60 \mathrm{~m}$ deep crater from rim to water surface has an inclination of $50 \%$ and more. Numerous little creeks flow into the lake, which has one large outflow in the West that falls over a ca. $5 \mathrm{~m}$ high cascade.

\section{Ar/39Ar dating}

Using the 40Ar/39Ar method, whole-rock or mineral samples can be dated by determining the ratio of radiogenic 40Ar to neutron-induced 39Ar. An in-situ volcanic rock sample was collected on the northern shore of Lake Amparihibe (15².207'S; 49 34.963'E) and analysed at the Department of Geology of the University of Salzburg. A detailed description of the methodology can be found in Rieser et al. (2007).

\section{Limnology}

Water samples were taken in the central part of the lake from an anchored dinghy. In the afternoon of November 12, 2007, water temperature, oxygen concentration and saturation, conductivity and $\mathrm{pH}$ were measured with portable devices (Hanna Instruments) at $0,5,7.5,10,12.5,15,20$ and $25 \mathrm{~m}$ depth. On November 13, 2007, two series of zooplankton samples were collected with a 4.51 Schindler-Patalas trap at 0 , $2.5,5,10,15,20$, and $25 \mathrm{~m}$ depth, filtered through a $30 \mu \mathrm{m}$ mesh and preserved in $4 \%$ formaldehyde. Ad-

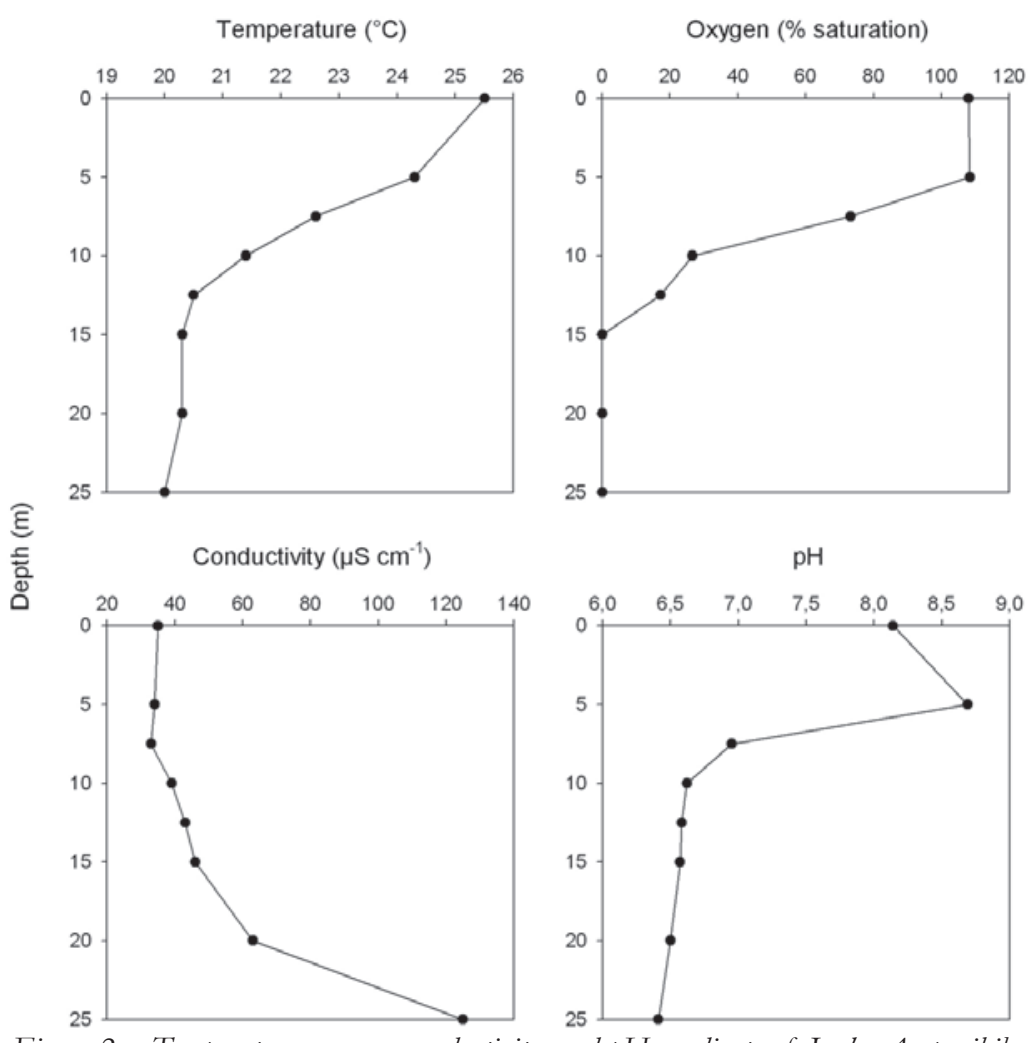

Figure 2 - Temperature, oxygen, conductivity, and $p H$ gradients of Lake Amparibibe on November 12, 2007.

ditionally, phytoplankton samples $(100 \mathrm{ml})$ were collected at $0,5,10$ and $15 \mathrm{~m}$ depth and preserved with Lugol's iodine. In the laboratory, zooplankton samples were stained with Rosé Bengal. Phytoplankton analyses followed Rott's (1981) recommendations for counting and biovolume calculations using the Utermöhl technique. For phytoplankton species identifications a larger set of literature relevant also to tropical environments was used (e.g. Komarek \& Fott 1983; Rott et al. 2008). The entire zooplankton sample was counted under an inverted microscope.

A standardized multimesh gill net was exposed overnight from the shoreline outwards to the lake centre (30 m length, $1.5 \mathrm{~m}$ width; 12 mesh sizes: 5, 6.25, 8, 10, $12.5,15.5,19.5,24,29,35,43,55 \mathrm{~mm})$. Additionally, we snorkelled around the shoreline and screened the littoral habitats for the presence of fish.

\section{Results}

\section{Ar/39Ar dating}

The dated volcanic rock yielded an isochron age of $25.3 \pm 1.2 \mathrm{Ma}$ (initial 40Ar/39Ar = $299 \pm 9$ ).

\section{Abiotic parameters}

The water body of the protected crater lake was stratified: Temperature dropped from $25.5^{\circ} \mathrm{C}$ at the surface to $21.4^{\circ} \mathrm{C}$ at $10 \mathrm{~m}$ depth and reached $20.0^{\circ} \mathrm{C}$ above the sediment (Figure 2). Correspondingly, a strong oxycline was observed between 5 (128\% saturation) and $10 \mathrm{~m}(27 \%)$. Beyond $15 \mathrm{~m}$ the hypolimnion was anoxic and conductivity increased from 43 to $125 \mu \mathrm{S}$ 


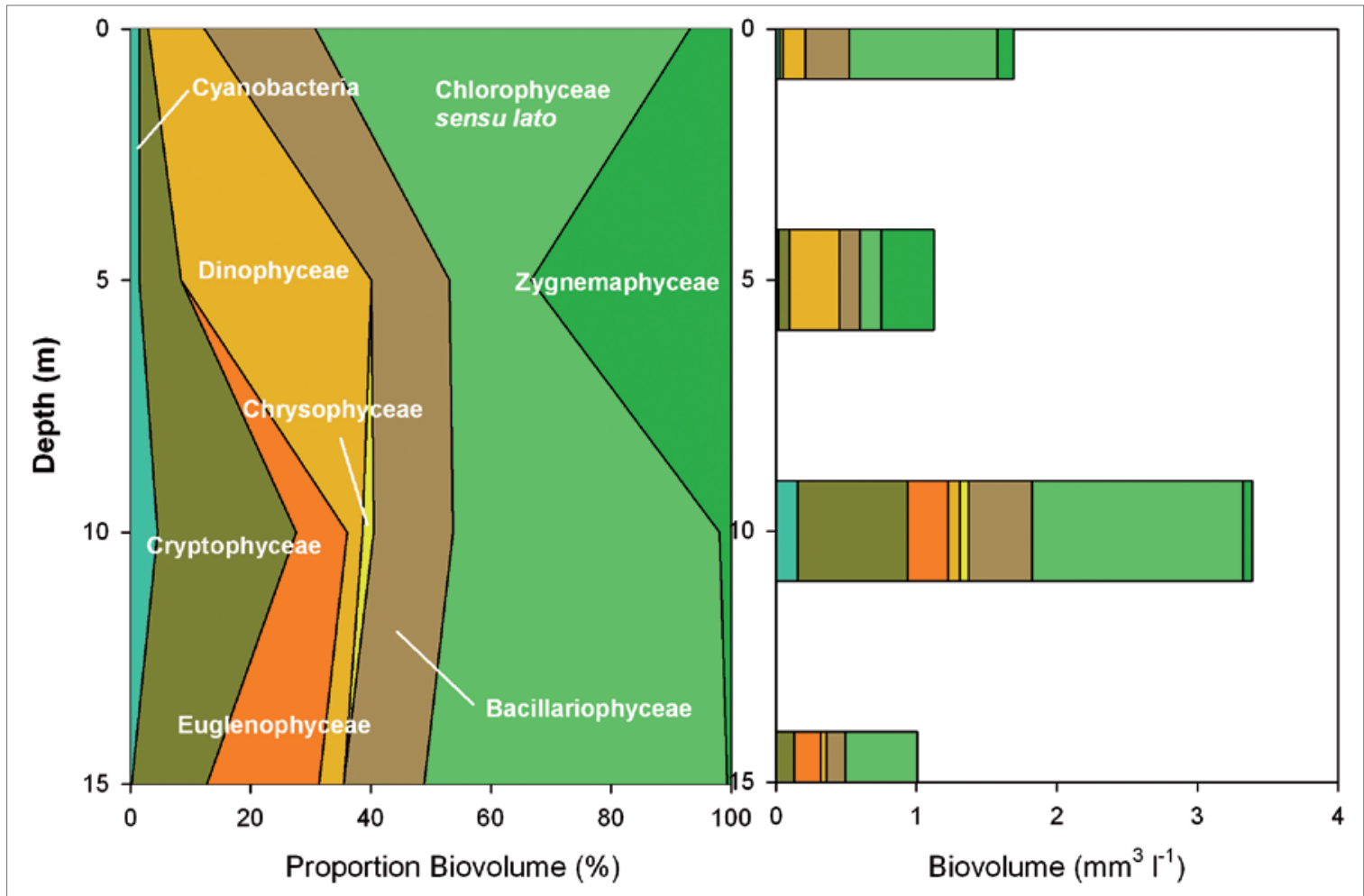

Figure 3 - Vertical distribution of the different groups of algae in Lake Amparibibe, shown as relative proportion of biovolume (left) and absolute biovolume (right).

$\mathrm{cm}^{-1}$ in $25 \mathrm{~m}$, thereby increasing stability of the water body. The $\mathrm{pH}$ increased from 8.1 to 8.7 in the top five meters and then dropped to 6.4 above ground. The oversaturation with oxygen and increased $\mathrm{pH}$-values in the top layers were related to peak abundances of small desmids (see below).

\section{Phytoplankton}

A total of approximately 42 taxa were recorded including a few characteristic African taxa (e.g. Cylindrospermopsis africana, Peridinium africanum), but so far no new species were discovered (Table 1). In terms of biovolume, Chlorophyceae dominated the phytoplankton with mostly minute single-celled taxa (e.g. Chlorella, Monoraphidium, Nephrochlamys), except for subsurface layers around $5 \mathrm{~m}$ depth, where Zygenmaphyceae (three or more minute Cosmarium-like taxa $<10 \mu \mathrm{m}$, with high shape variability for which preliminary names are listed in Table 1) and Dinophyceae prevailed (Figure 3). Euglenophyceae and Cyanobacteria reached highest abundance at low oxygen conditions around $15 \mathrm{~m}$ depth. Overall algal biomass was highest in layers below $\mathrm{pH}$ and oxygen maxima.

\section{Zooplankton}

Seven species of rotifers dominated the zooplankton community in the oxygenated layers (Table 1). They exhibited a clear depth segregation (Figure 4), with Polyarthra vulgaris dominating at the surface, Hexarthra intermedia at $2.5 \mathrm{~m}$, and the Trichocerca species at $5 \mathrm{~m}$, whereas Anuraeopsis fissa reached its highest abundance together with a gastrotrich species (Neogossea cf. anten- nigera) within the chemocline. Early cyclopoid copepodites and Chaoborus cf. ceratopogones larvae were most abundant in shallow subsurface layers. A maximum of the ciliate Pelatractus sp. was found at the upper boundary layer of the hypolimnion.

\section{Fish}

No fish were seen or caught. Nevertheless the presence of eels (Anguilla spp.) cannot be excluded.

\section{Discussion}

The 40Ar/39Ar dating showed that the crater of Lake Amparihibe probably formed during the Tertiary and hence is much older than the numerous craters in the large volacanic complex of the Montagne d'Ambre north of the Makira Protected Area (Schleicher 2009). Since the major focus of this study was a limnological characterization of the lake, the age estimate from a single rock sample has to be treated as a preliminary result. Nor do we have any information when the crater filled with water to become a permanent lake, because no sediment cores were taken. Nevertheless these first results show that Lake Amparihibe is one of the few old freshwater ecosystems far from any human settlement and is therefore particularly interesting for the investigation of pristine freshwater species assemblages in Madagascar.

The clear stratification of Lake Amparihibe and its protected position within the crater suggests that it remains stratified throughout the year or at least for long periods, although more sampling, especially after 
cyclones have hit the lake, would be required to confirm a permanent anoxic hypolimnion. During our sampling, only the top $15 \mathrm{~m}$ of the open water, together with a relatively narrow belt of benthic habitat, could be colonized by aerobic organisms. Concordantly, most planktonic species exhibited clear depth-specific maxima in abundance. Different dominant taxa of both phyto- and zooplankton were found in the different layers of the epilimnion (desmids, dinoflagellates, most rotifers), the oxycline (Cryptomonas spp., Cyanobacteria, Gastrotricha, Anuraeopsis fissa), and the upper layers of the anoxic hypolimnion (Trachelomonas sp., Pelatractus sp.; Figures $3+4)$.

Nevertheless we found aerobic phyto- and zooplankton organisms in complete anoxia that did not show any signs of deterioration. Several authors report algae, rotifers and crustaceans in extremely hypoxic or oxygen-free waters (Green et al. 1973; Kizito et al. 1993; Kizito \& Nauwerck 1995). In a previous study we encountered undamaged phyto- and zooplankton organisms in complete darkness and anoxia at $82 \mathrm{~m}$ depth within the crater lake Loreto on Bioko Island, Equatorial Guinea (Schabetsberger et al. 2004). The reasons are probably passive downward transport processes such as sedimentation or entrapment within cooler water masses.

The presence of a considerable portion of mid-sized diatoms throughout the water column (including Fragilaria crotonensis and Ulnaria acus) indicates that the lake may overturn during certain periods of the year. On the other hand, the presence of the potentially bloomforming colonial Cyanobacterium Microcystis aeruginosa in $10 \mathrm{~m}$ depth, below the $\mathrm{pH}$ and oxygen maxima, may be indicative for the sedimentation of algal cells from a preceding bloom during warmer periods of the year. Some phyto- and zooplankton organisms could only be determined to genus or even higher taxonomic level, but among those taken to species level by morphological analyses, we did not discover any new or endemic taxa within this remote crater lake. The rarest species we detected was the rotifer Trichocerca agnatha, which so far has only been recorded from the type locality in Germany (Wulfert 1939), from Australia (Koste \& Shiel 1980), and from a crater lake on the Malagasy island of Nosy Be (Segers 1992).
Individuals I $^{-1}$
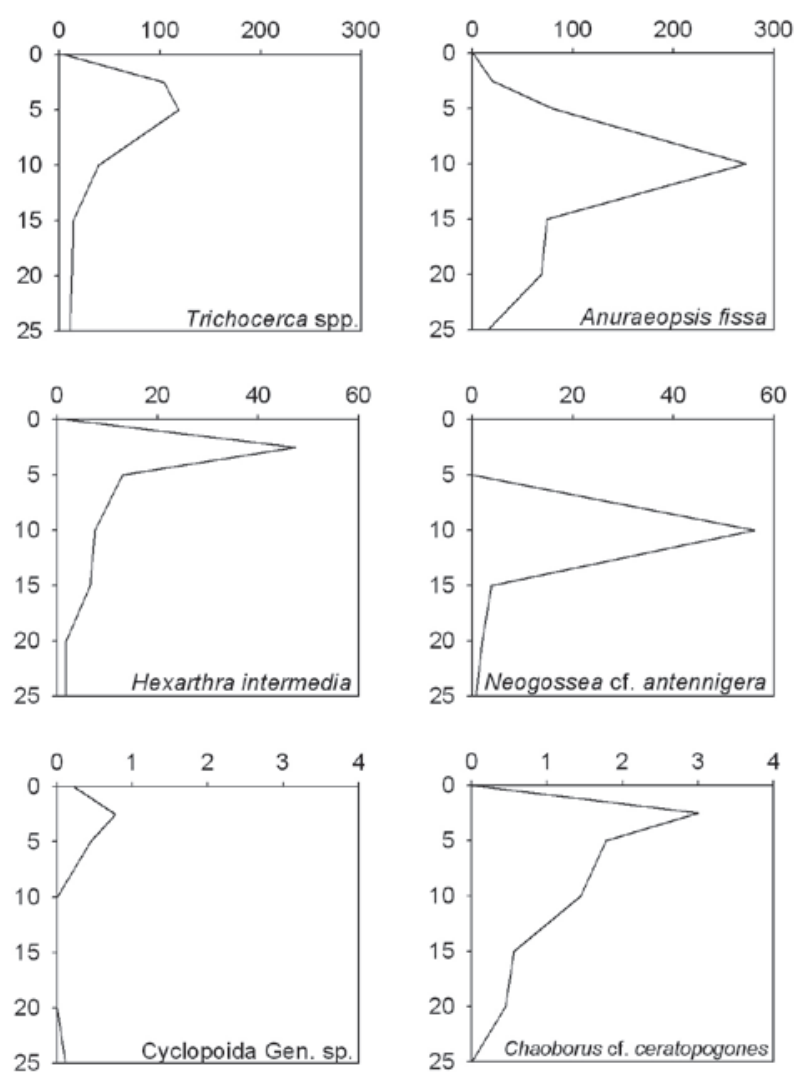

Figure 4 - Vertical distribution of the dominant rooplankton taxa in Lake Amparibibe.

Further detailed taxonomic research is required here and for other pristine lake ecosystems of Madagascar to understand better if endemic freshwater plankton organisms developed on the island continent. In this preliminary study of Lake Amparihibe, species with a wide distribution prevailed. Accordingly, in the extremely isolated lakes on South Pacific Islands endemics were only encountered within the Crustacea (Schabetsberger et al. 2009). However, the sole cyclopoid copepod in the lake could not be identified, as it was only present as early copepodites. Yet it remains a matter of debate if the propagules of smaller phyto- and zooplankton organisms are readily distributed by wind, rain or water birds (Bilton et al. 2001; Bohonak et al. 2003). In the future, standard alpha-taxonomy backed by genetic analysis of e.g. cryptic species (Mann \& Droop 1996) will help to solve this complex question. Fish probably never colonized the lake, since they were neither caught in the multimesh gill net nor observed while snorkelling. The outflow of the lake falls over a cascade that forms an insurmountable obstacle for migrating fish. We cannot exclude the presence of eels (Anguilla spp.), that are known to crawl over wet soil during heavy rains and may remain hidden during daylight.

Lake Amparihibe remains surrounded by intact low altitude eastern forest and is situated well within the limits of the strict protection zone of the Makira Protected Area. However, we believe that stocking with fish poses a realistic threat to the lake. At least 24 alien 
Table 1 - Phyto- and zooplankton species found in Lake Amparibibe, Madagascar

\begin{tabular}{|c|}
\hline PHYTOPLANKTON \\
\hline Cyanobacteria \\
\hline Anabaena sp. \\
\hline Cylindrospermopsis africana J. Komárek \& H. Kling 1991 \\
\hline $\begin{array}{l}\text { Planktolyngbya limnetica (Lemmermann) } \\
\text { J. Komárková-Legnerová \& G. Cronberg } 1992\end{array}$ \\
\hline Microcystis aeruginosa (Kützing) Kützing 1846 \\
\hline Merismopedia tenuissima Lemmermann 1898 \\
\hline Oscillatoria sp. \\
\hline Cryptophyceae \\
\hline Cryptomonas spp. $(20 \mu \mathrm{m}, 27 \mu \mathrm{m})$ \\
\hline Euglenophyceae \\
\hline Trachelomonas cf. abrupta Svirenko 1914 \\
\hline Trachelomonas cf. volvocina Ehrenberg 1833 \\
\hline Dinophyceae \\
\hline Gymnodinium spp. $(15 \mu \mathrm{m}, 30 \mu \mathrm{m})$ \\
\hline Peridiniopsis elpatiewskyi (Osternfeld) Bourrelly 1968 \\
\hline Peridinium africanum Lemmermann 1907 \\
\hline Peridinium spp. \\
\hline Chrysophyceae \\
\hline Chrysoflagellate unidentified ( $8 \mu \mathrm{m})$ \\
\hline Bacillariophyceae \\
\hline Asterionella formosa Hassall 1850 \\
\hline Aulacoseira granulata (Ehrenberg) Simonsen 1979 \\
\hline Cyclotella meneghiniana Kützing 1844 \\
\hline Cyclotella sp. $(5 \mu \mathrm{m})$ \\
\hline Fragilaria crotonensis Kitton 1869 \\
\hline Synedra spp. $(40 \mu \mathrm{m}, 70 \mu \mathrm{m})$ \\
\hline Ulnaria acus (Kützing) M. Aboal 2003 \\
\hline Urosolenia cf. pusilla Rott \& Kling 2006 \\
\hline Chlorophyceae \\
\hline Ankistrodesmus cf. falcatus (Corda) Ralfs 1848 \\
\hline Botryococcus sp. \\
\hline Chlorella sp. \\
\hline Coelastrum proboscideum Bohlin in Wittrock \& Nordstedt 1896 \\
\hline Crucigenia tetrapedia (Kirchner) W. West \& G.S. West 1902 \\
\hline Dictyopshaerium sp. $(3 \mu \mathrm{m})$ \\
\hline Franceia cf. polychaeta (Širšov) Korshikov 1953 \\
\hline
\end{tabular}

species have been introduced into Madagascar's lakes and rivers (Benstead et al. 2003 and references therein). Tilapias (Oreochromis spp., Tilapia spp., Sarotherodon spp.) are readily available, handy to transport and would serve as an easy to catch source of protein. Due to size-selective predation, fish would irreversibly change both species composition and abundance of the natural community. In remote crater lakes on South Pacific Islands we found reduced species richness in stocked versus unstocked lakes (Schabetsberger et al. 2009). In the particular case of Lake Amparihibe the threat of stocking could most likely originate from out-ofcontrol movements of local inhabitants through the forests. It is important to note that a population of more than 150000 inhabitants resides in the border forest landscape of the protected area. An additional threat is represented by illegal harvesting of hardwoods from within the park. Encampments near the lake could invite introduction of fish into the lake.

\begin{tabular}{|l|}
\hline PHYTOPLANKTON \\
\hline Micractinium cf. pusillum Fresenius 1858 \\
\hline Monoraphidium contortum (Thuret) Komàrková-Legnerová 1969 \\
\hline Monoraphidium sp. \\
\hline Nephrochlamys sp. ad N. subsolitaria (G.S. West) Korshikov 1953 \\
\hline Tetraedron minimum (A. Braun) Hansgirg 1888 forma! \\
\hline Treubaria triappendiculata C. Bernard 1908 \\
\hline Volvocales undidentiefied (8 4 m) \\
\hline Zygnemaphyceae \\
\hline Closterium sp. (40 $\mu$ m) \\
\hline Cosmarium cf. pusillum (Brébisson) W. Archer 1861 \\
\hline Cosmarium cf. regnesii Reinsch 1867 \\
\hline Cosmarium cf. subcapitulum West \& West f. minor Taylor 1934 \\
\hline Mougeotia sp. \\
\hline Staurastrum sp. \\
\hline
\end{tabular}

\begin{tabular}{|l|}
\hline ZOOPLANKTON \\
\hline Protozoa \\
\hline Pelatractus sp. \\
\hline Urotricha sp. \\
\hline Rotifera \\
\hline Anuraeopsis fissa Gosse 1851 \\
\hline Collotheca sp. \\
\hline Hexarthra intermedia Wiszniewski 1929 \\
\hline Polyarthra vulgaris Carlin 1943 \\
\hline Trichocerca agnatha Wulfert 1939 \\
\hline Trichocerca pusilla Lauterborn 1898 \\
\hline Trichocerca ruttneri Donner 1953 \\
\hline Gastrotricha \\
\hline Neogossea cf. antennigera Gosse 1851 \\
\hline Copepoda Cyclopoida \\
\hline unidentified copepodites \\
\hline Chaoboridae \\
\hline Chaoborus (Sayomyia) cf. ceratopogones Theobald 1903 \\
\hline
\end{tabular}

The Madagascar Ministry of Environment, Forests and Tourism has delegated the management authority of the Makira Protected Area to the Wildlife Conservation Society. The Society is currently engaged in a program of community forest resource management. Principal components of this program are education and awareness campaigns to improve community land stewardship. Such information campaigns and continuous controls by park field agents are necessary to keep the lake fishfree. In addition, more efforts should be made to survey and study the few remaining pristine lakes in Madagascar. Continued ecological and taxonomic research in combination with better management strategies is vital to safeguard their biodiversity. 


\section{Acknowledgments}

Two anonymous reviewers critically read the manuscript and provided helpful comments. We are indebted to Rupert Lenzenweger (Zygnemaphyceae), Wilhelm Foissner (Ciliata), Christian Jersabek (Rotifera), Maria Balsamo (Gastrotricha) and Rüdiger Wagner (Chaoboridae) for species identification. Johann Genser helped with the age determination of the rock sample. We thank Aristide Andrianarimisa and Noromalala Raminosoa for logistic support and Jacky Andriantiana, Petra and Bernd Stolle, Gunter Fischer and the many porters from the villages of Ambinanitelo und Sahantaha for help during field work. Hanitra Rakoto produced the map. This research was conducted under permit 0240/07 issued by the Ministère de l'Environment, des Eaux et Forets, Madagascar.

\section{References}

Berzins, B. 1960. Neue Rotatorienarten aus Madagaskar. Mémoires de l' Institut Scientifique de Madagascar 14: 1-6.

Berzins, B. 1973. Zwei neue Euchlanis -Arten, Rotatoria. Zoologischer Anzeiger 190: 125-127.

Berzins, B. 1982. Zur Kenntnis der Rotatorienfauna Madagaskars. Lund. AV centralen i. Lund: 24 pp.

Benstead, J.P., P.H. DeRham, J.-L. Gattolliat, F.-M. Gibon, P.V. Loiselle, M. Sartori, J.S. Sparks \& M.L.J. Stiassny 2003. Conserving Madagascar's freshwater biodiversity. BioScience 53: 1101-1111.

Bilton, D.T., J.R. Freeland \& B. Okamura 2001. Dispersal in freshwater invertebrates. Annual Reviews in Ecology and Systematics 32: 159-181.

Bohonak, A.J. \& D.G. Jenkins 2003. Ecological and evolutionary significance of dispersal by freshwater invertebrates. Ecology Letters 6: 783-796.

Bourrelly, P. \& A. Couté 1991. Desmidiées de Madagascar. Bibliotheca Phycologica 86. Berlin-Stuttgart.

Bourrelly, P. \& R. Leboime 1946. Notes sur quelques algues d'eau douce de Madagascar. Biologisch Jaarboeck, Dodonea 13: 75-111.

Bourrelly, P. \& E. Manguin 1949. Contribution à l'étude de la flore algale d'eau douce de Madagascar. Le lac de Tzimbazaza. Mémoires de l' Institut Scientifique de Madagascar 2: 161-190.

Brehm, V. 1930. Notizen zur Cladocerenfauna Madagaskars. Archiv für Hydrobiologie 21: 679-686.

Brehm, V. 1948. Nuevos copepodos de Madagascar. Publicaciones Instituto de Biologia Aplicada 5: 77-84. Barcelona.

Brehm, V. 1951. Pseudodiaptomus pauliani. Der erste Vertreter der Pseudodiaptomiden in der madegassichen Fauna. Mémoires de l' Institut Scientifique de Madagascar 6: 419-425.

Brehm, V. 1952a. Cladoceren und calanoide Copepoden von Madagaskar. Mémoires de l' Institut Scientifique de Madagascar 7: 37-46.

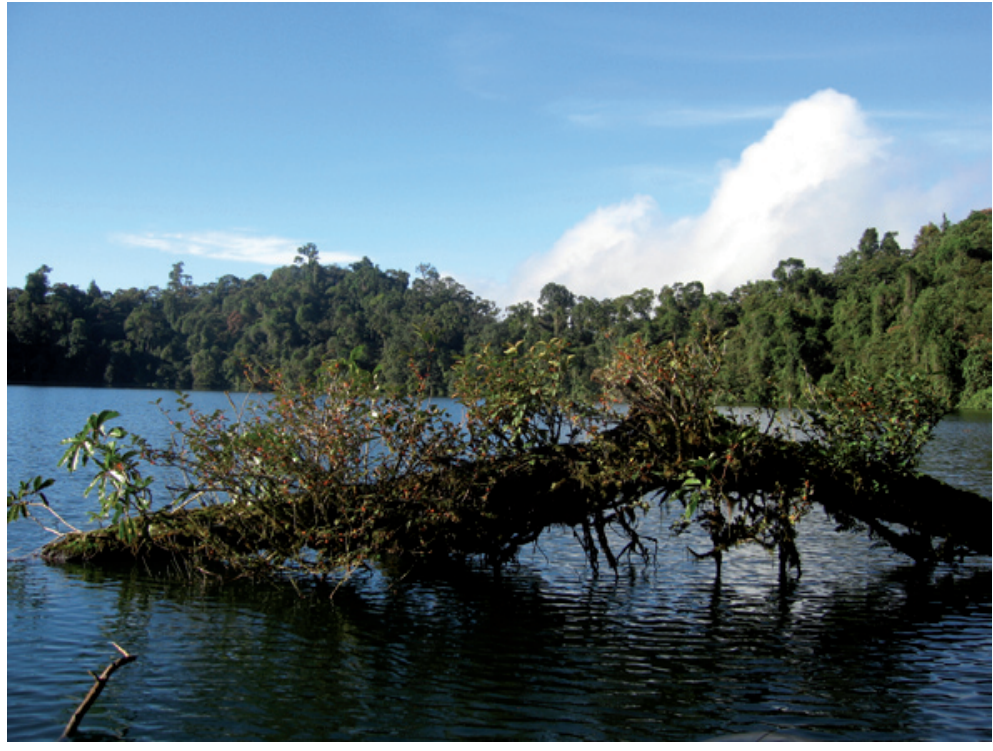

Lake Amparibibe (C) Gabriele Drozdowski

Brehm, V. 1952b. Anadiaptomus madagascariensis Rylov (Copepoda Diaptomidae). Le Naturaliste Malgache 3: 159-162.

Brehm, V. 1952c. Anadiaptomus poseidon nov. gen., nov. spec. aus Madagascar. Anzeiger der Österreichischen Akademie der Wissenschaften 89: 23-27.

Brehm, V. 1953. Cladocères et copépodes calanoides de Madagascar. Le Naturaliste Malgache 5: 151-152.

Brehm, V. 1954. Pseudodiaptomus batillipes, spec. nov., Ein zweiter Pseudodiaptomus aus Madagascar. Sitzungsberichte der Österreichischen Akademie der Wissenschaften, Mathematisch - Naturwissenschaftliche Klasse 1: 603-607.

Brehm, V. 1960. Ergebnisse der österreichischen Madagaskar-Expedition 1958: 1. Beitrag zur Kenntnis der Crustacea madegassischer Stillgewässer. Mémoires de l' Institut Scientifique de Madagascar 14: 39-58.

Chappuis, P.A. 1952. Copépodes harpacticoides psammiques de Madagascar. Mémoires de l' Institut Scientifique de Madagascar 7: 145-160.

Chappuis, P.A. 1954. Recherches sur la faune interstitielle des sediment marins et d'eau douce a Madagascar. IV. Copépodes harpacticoides psammiques de Madagascar. Mémoires de l' Institut Scientifique de Madagascar 9: 45-73.

Chappuis, P.A. 1956. Presence a Madagascar du genre Echinocamptus: E. pauliani n.sp.. Mémoires de l' Institut Scientifique de Madagascar 10: 35-42.

Coesel, P.F.M. 2002. Taxonomic and biogeographical notes on Malagassy desmids (Chlorophyta, Desmidiaceae). Nordic Journal of Botany 22: 239-256.

DeGuerne J. \& J. Richard 1893. Canthocamptus grandidieri, Alona cambonei, nouveaux entomostraces d'eau douce de Madagascar. Mémoires de la Societé Zoologique de France 96: 234-244.

Dumont, H.J. 1983. Biogeography of rotifers. Hydrobiologia 104: 19-30.

Dussart, B.H. 1982. Crustacés Copèpodes des eaux intérieures. Faune de Madagascar 58. Paris: ORSTOM, CNRS. 
Fenchel, T. \& B.J. Finlay 2004. The ubiquity of small species: patterns and local and global diversity. BioScience 54: 777-784.

Fiers, F. 2002. The genus Haplocyclops Kiefer, 1952 (Copepoda, Cyclopoida, Cyclopidae): Redescription of the type-species, H. gudrunae, and its congeners. $H y$ drobiologia 474: 155-169.

Fritsch, F.E. 1914. Contribution to our knowledge of the freshwater algae of Africa. I. Some freshwater algae from Madagascar. Annales de Biologie Lacustre 7: 40-59.

Green, G.M. \& R.W. Sussman 1990. Deforestation history of the eastern rain forests of Madagascar from satellite images. Science 248: 212-215.

Green, J., S.A. Corbet \& E. Betney 1973. Ecological studies on crater lakes in West Cameroon. The blood of endemic cichlids in Barombi Mbo in relation to stratification and their feeding habits. Journal of Zoology London, 170: 299-308.

Groombridge, B. \& M. Jenkins 1998. Freshwater Biodiversity. A preliminary global assessment. WCMC Biodiversity Series 8. Cambridge (UK).

Hansen, P. 1996. Silica-scaled Chrysophyceae and Synurophycea from Madagascar. Archiv für Protistenkunde 147: 145-172.

Harper, G.J., M.C. Steininger, C.J. Tucker, D. Juhn \& F. Hawkins 2007. Fifty years of deforestation and forest fragmentation in Madagascar. Environmental Conservation 34: 325-333.

Kiefer, F. 1930. Zur Kenntnis freilebender Copepoden Madagaskars. Zoologischer Anzeiger 87: 42-46.

Kiefer, F. 1952. Haplocyclops gudrunae n.gen. et n.sp., ein neuer Ruderfußkrebs (Crustacea Copepoda) aus Madagaskar. Zoologischer Anzeiger 149: 240-243.

Kiefer, F. 1954. Neue Cyclopoida Gnathostoma (Crustacea Copepoda) aus Madagaskar. I. Cyclopininae and Halicyclopinae. Zoologischer Anzeiger 153: 308-313.

Kiefer, F. 1955. Neue Cyclopoida Gnathostoma (Crustacea Copepoda) aus Madagaskar. II. Cyclopinae. Zoologischer Anzeiger 154: 222-232.

Kizito, Y.S. \& A. Nauwerck 1995. The distribution of planktonic rotifers in Lake Nkuruba, Western Uganda. Limnologica 26: 263-273.

Kizito, Y.S., A. Nauwerck, L.J. Chapman \& W. Koste 1993. A limnological survey of some Western Uganda crater lakes. Limnologica 23: 335-347.

Komárek, J. \& B. Fott 1983. Chlorococcales. In G. Huber-Pestalozzi (ed.), Das Phytoplankton des Süßwassers 7 (1). Die Binnengewässer XVI. Stuttgart. 1043 pp.

Koste, W. \& R. Shiel 1980. New Rotifera from Australia. Transactions of the Royal Society of South Australia 104: 133-144.

Kristiansen, J. \& J.F. Lind 2005. Endemicity in silicascaled chrysophytes. Nova Hedwigia Beihefte 128: 65-83.

Lindberg, K. 1951a. Cyclopides de Madagascar. I. Mémoires de l' Institut Scientifique de Madagascar 5: 187-195.

Lindberg, K. 1951b. Cyclopides de Madagascar. II. Mémoires de l' Institut Scientifique de Madagascar 6: 427-437.
Lindberg, K. 1952. Cyclopides de Madagascar. III. Mémoires de l' Institut Scientifique de Madagascar 7: 53-67. Lindberg, K. 1953. Cyclopides de Madagascar. IV. Mémoires de l' Institut Scientifique de Madagascar 8: 11-17.

Manguin, E. 1941. Contribution à la connaisance des Diatomées d'eau douce de Madagascar. Revue Algologique 12: 153-157.

Mann, D.G. \& J.M. Droop 1996. Biodiversity, biogeography and conservation of diatoms. Hydrobiologia 336: 19-22.

Metzeltin, D. \& H. Lange-Bertalot 2002. Diatoms from the "Island Continent" Madagascar. Iconographia Diatomologica, 11. Königstein.

Moreau, J. 1988. Region 9, Madagascar. In: Davies, B. \& F. Gasse (eds.), Zones humides et lacs peu profonds d'Afrique: bibliographie. Travaux et documents de l'ORSTOM 211: 469-485.

Rabinowitz, P.D., M.F. Coffin \& D. Falvey 1983. The separation of Madagascar and Africa. Science 220: 67-69.

Raval, U \& K. Veeraswamy 2003. India-Madagascar Separation: Breakup along a pre-existing mobile beltand chipping of the craton. Gondwana Research 6: 467-485. Rieser, A.B., Y. Liu, J. Genser, F. Neubauer, R. Handler, G. Friedl \& X. Ge 2007. 40Ar/39Ar ages of detrital white mica constrain the Cenozoic development of the intracontinental Qaidam Basin, China. GSA Bulletin 118: 1522-1534.

Rott, E. 1981. Some results from phytoplankton counting intercalibrations. Schweizerische Zeitschrift für Hydrologie 43: 34-63.

Rott, E., E.I.L. Sila, E. Enriquez \& S. Ingthamjitr 2008. Phytoplankton community structure with special reference to species diversity in five tropical Asian water bodies. In: Schiemer, F., D. Simon, U. Amarasinghe \& J. Moreau (eds.), Aquatic ecosystems and development: Comparative Asian perspectives: 81-120. Weikersheim and Leiden.

Schabetsberger, R., G. Drozdowski, I. Drozdowski, D. Jersabek \& E. Rott 2004. Limnological aspects of two tropical crater lakes (Lago Biao and Lago Loreto) on the island of Bioko (Equatorial Guinea). Hydrobiologia 524: 79-90.

Schabetsberger, R., G. Drozdowski, E. Rott, R. Lenzenweger, C.D. Jersabek, F. Fiers, W. Traunspurger, N. Reiff, F. Stoch, A.A. Kotov, K. Martens, H. Schatz \& R. Kaiser 2009. Losing the bounty? Investigating species richness in isolated freshwater ecosystems of Oceania. Pacific Science 63: 153-181.

Schleicher, H. 2009. Petrologic research in Madagascar. Available at: http://www1.uni-hamburg.de/mpi/ staff/schleicher/PETROLOGIE-WEB2/MadVneu. htm (accessed: 25/02/09)

Segers, H. 1992. Taxonomy and zoogeography of the rotifer fauna of Madagascar and the Comoros. Journal of African Zoology 106: 351-361.

Spaulding S.A. \& J.P. Kociolek 1998a. New Gomphonema (Bacillariophyceae) species from Madagascar. Proceedings of the California Academy of Sciences 50: 361-379. 
Spaulding S.A. \& J.P. Kociolek 1998b. The Diatom Genus Orthoseira: Ultrastructure and morphological variation in two species from Madagascar with comments on nomenclature in the genus. Diatom Research 13: 133-147.

Tyson, P. 2000. The Eighth Continent: Life, Death and Discovery in the Lost World of Madagascar. New York.

West, W. \& G. West 1895. A contribution to our know-ledge of the freshwater algae of Madagascar. Transactions of the Linnean Society London, Botany 5: 41-90.

Wildlife Conservation Society 2008a. Makira Conservation Site. Available at: http://www.wcs.org/globalconservation/Africa/madagascar/makira (accessed: 25/02/09)

Wildlife Conservation Society 2008b. WCS Makira Protected Area Environmental and Social Impact Assessment. Antananarivo, Madagascar.

Wulfert, K. 1939. Einige neue Rotatorien aus Brandenburg und Pommern. Zoologischer Anzeiger 127: 65-75.

\section{Authors}

\section{Robert Schabetsberger}

Born 1963. Doctoral thesis on food webs in alpine lakes. Fisheries biologist in the North Pacific from 1996-2002. Currently lecturer at the universities of Salzburg and Vienna.

Robert.Schabetsberger@sbg.ac.at.

\section{Gabriele Drozdowski}

Born 1980. Masters thesis on the top-down effects of introduced fish in high-altitude lakes. Currently working as a freelance biologist.

${ }^{1}$ Division of Organismal Biology, University of Salzburg, Hellbrunnerstraße 34, 5020 Salzburg, Austria.

\section{Eugen Rott}

Born 1951. Doctoral thesis on phytoplankton in the Piburgersee in Austria in 1975. Since 1982 his work has focussed on tropical phytoplankton diversity. Currently associated professor at the Institute of Botany at the University of Innsbruck.

${ }^{2}$ Institute of Botany, University of Innsbruck, Sternwartestraße 15, 6020 Innsbruck, Austria.

\section{Gertrude Friedl}

Born 1964. Doctoral thesis on U-Pb geochronology of magmatic and metamorphic rocks from the Bohemian Massif in Austria. Currently member of the working group geology at the University of Salzburg, where she is also teaching.

${ }^{3}$ Department of Geology, University of Salzburg, Hellbrunnerstraße 34, 5020 Salzburg, Austria.

\section{Estelle Fenohanta Razafindranaivo}

Born 1979. DEA degree thesis on food of Oreochromis niloticus in Madagascar. Currently working as a consultant ichthyologist.

${ }^{4}$ University of Antananarivo, Faculty of Sciences, Department of Animal Biology, B.P. 906, 101 Antananarivo, Madagascar.

\section{Christopher Holmes}

Born 1968. Doctoral thesis on theoretical modeling of human land-use decision-making in the Katavi protected area of Tanzania, East Africa. From 2001-2004 post-doctoral researcher based in Madagascar with the Institute for Conservation of Tropical Environments, Stony Brook University, NY. Since 2004 he has been working with the Wildlife Conservation Society, Madagascar Program where he is the Technical Director for the WCS country program.

${ }^{5}$ Wildlife Conservation Society, Villa Ifanomezantsoa, Soavimbahoaka, BP 8500, Antananarivo 101, Madagascar. 